in head and neck intensity-modulated radiation therapy. Med Dosim 2011;36:41-45.

5. Monroe AT, Reddy SC, Gibbs GL, White GA, Peddada AV. Factors associated with radiation-induced nausea and vomiting in head and neck cancer patients treated with intensity modulated radiation therapy. Radiother Oncol 2008;87:188-194.

IMMUNE RECONSTITUTION INFLAMMATORY SYNDROME IN NATALIZUMAB-ASSOCIATED PML

Remy Phan-Ba, Emile Lommers, Gustave Moonen, Shibeshih Belachew, Liege, Belgium: Tan et al. ${ }^{1}$ dichotomized early vs late types of the immune reconstitution inflammatory syndrome (IRIS), which appears to be universal in patients with multiple sclerosis (MS) who develop progressive multifocal leukoencephalopathy (PML) in the setting of natalizumab therapy.

The authors identified early PML-IRIS based on gadolinium enhancement in the lesions on brain MRI at the time of PML diagnosis, before natalizumab withdrawal. Early PML-IRIS occurred approximately 19 days after the last natalizumab infusion when natalizumab effect on alpha4-integrin binding remained optimal. ${ }^{2}$ Hence, inflammatory MRI signs of this early PML-IRIS take place in the absence of ongoing restoration of the immune competence within the brain. This is different from what is seen in HIV-related PML where IRIS occurs only after inducing the immune reconstitution through the initiation of anti-retroviral therapy. ${ }^{3}$

Early PML-IRIS in natalizumab-associated PML may only represent radiologic signs of blood-brain barrier alteration due to JC virus infection in this specific context. The operational definition of early PML-IRIS should be early infection-related or idiopathic radiologic inflammatory syndrome vs delayed IRIS, which truly reflects an immune reconstitution. The prognostic factors, responsiveness to steroid administration and to plasma exchanges, should then be evaluated separately for these 2 distinct conditions.

Author Response: Avinda Nath, Bethesda, MD: We thank Phan-Ba et al. for their suggestions on how to better define the 2 different forms of PML-IRIS. We attempted to develop terminology that could be used not only for patients with MS who develop PML but other immune-compromised states such as HIV infection or organ transplants. Typically, in immune-suppressed individuals who develop PML, there is no evidence of inflammation so any inflammation in the early or late stage is a form of immune reconstitution. Furthermore, PML-IRIS is not always a radiologic diagnosis. The enhancement associated with PML-IRIS on MRI can be very subtle or not noticeable to the naked eye particularly in HIVinfected and organ transplant patients. ${ }^{4}$ We prefer the term "early PML-IRIS" to define individuals who have evidence of IRIS at the time of diagnosis of PML and "delayed PML-IRIS" to define individuals who were known to have PML but develop IRIS later in the course of the illness usually associated with an improvement of the underlying immune dysfunction.

Copyright (C) 2012 by AAN Enterprises, Inc.

1. Tan IL, McArthur JC, Clifford DB, Major EO, Nath A. Immune reconstitution inflammatory syndrome in natalizumab-associated PML. Neurology 2011;77:1061-1067.

2. Khatri BO, Man S, Giovannoni G, et al. Effect of plasma exchange in accelerating natalizumab clearance and restoring leukocyte function. Neurology 2009;72:402-409.

3. Tan K, Roda R, Ostrow L, McArthur J, Nath A. PML-IRIS in patients with HIV infection: clinical manifestations and treatment with steroids. Neurology 2009;72:1458-1464.

4. Harrison DM, Newsome SD, Skolasky RL, McArthur JC, Nath A. Immune reconstitution is not a prognostic factor in progressive multifocal leukoencephalopathy. J Neuroimmunol 2011;238:81-86.

\section{PROGRESSIVE MULTIFOCAL LEUKOENCEPHALOPATHY IN A PATIENT WITHOUT IMMUNODEFICIENCY}

Nitin K. Sethi, Josh Torgovnick, New York: The case report by Tan et al. ${ }^{1}$ of a 62 -year-old man with progressive multifocal leukoencephalopathy (PML) without immunodeficiency was interesting given our experience with AIDS-related PML and current literature. $^{2}$ The authors assume that their patient's disease was due to reactivation of latent JC virus infection caused by a transient dysfunction of cellular immunity triggered by another subclinical viral infection such as parvovirus B19. A 60-year-old colleague of ours recently had acute mononucleosis and her comment was that she had not kissed enough boys when she was younger. Little is still known about what triggers JC virus activation and its primary manifestation varies in the immunosuppressed, minimally immunosuppressed, and the immunocompetent patient. Is it possible that this case reflects the manifestation of disease in a 60-year-old man contracting the virus acutely? This might explain the unusual protracted course of his illness. We suspect that mefloquine played no role in his recovery, which was likely spontaneous. ${ }^{3,4}$

Author Response: Justin C. McArthur, I.L. Tan, Baltimore; I.J. Koralnik, Boston: PML is classically caused by reactivation of JC virus in the context of immunosuppression, although the exact mechanism of reactivation remains unclear. We agree with Drs. Sethi and Torgovnick that little is known about the manifestations of JC virus in acute infection. However, it is unlikely that PML in our patient was 


\section{Neurology}

\section{Immune Reconstitution Inflammatory Syndrome in Natalizumab-Associated PML}

Remy Phan-Ba, Avinda Nath, Emile Lommers, et al. Neurology 2012;78;73

DOI 10.1212/01.wnl.0000410335.08123.dc

\section{This information is current as of December 26, 2011}

\section{Updated Information \&} Services

References

Permissions \& Licensing

Reprints including high resolution figures, can be found at: http://n.neurology.org/content/78/1/73.1.full

This article cites 4 articles, 3 of which you can access for free at: http://n.neurology.org/content/78/1/73.1.full\#ref-list-1

Information about reproducing this article in parts (figures,tables) or in its entirety can be found online at:

http://www.neurology.org/about/about_the_journal\#permissions

Information about ordering reprints can be found online: http://n.neurology.org/subscribers/advertise

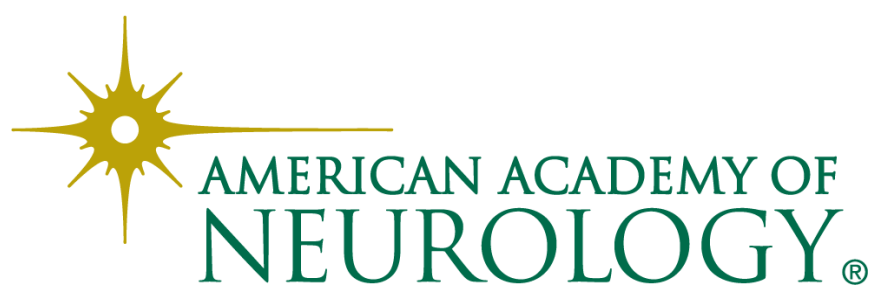

